\title{
Can Hydropower Drive Green Economy for Nepal: A Review
}

\author{
Ajay B. Mathema ${ }^{1,2}$, Shailendra Guragain ${ }^{1,2}$, Nawang C. Sherpa ${ }^{1,2}$, Binay B. Adhikari ${ }^{1,2}$ \\ ${ }^{1}$ Asian Center for Environment Management and Sustainable Development, Kathmandu, Nepal; ${ }^{2}$ School of Environmental Science \\ and Management, Pokhara University, Kathmandu, Nepal. \\ Email: ajaymathema1@gmail.com, abmathema@schems.edu.np
}

Received April 26 ${ }^{\text {th }}, 2013$; revised May 29 ${ }^{\text {th }}, 2013$; accepted June $28^{\text {th }}, 2013$

Copyright (C) 2013 Ajay B. Mathema et al. This is an open access article distributed under the Creative Commons Attribution License, which permits unrestricted use, distribution, and reproduction in any medium, provided the original work is properly cited.

\begin{abstract}
Economy is of importance for everyone but the growing environmental destruction and disparity between the rich and poor demands adoption of cleaner and better path so as to secure the future resources and achieve sustainable development with better social inclusion. On this regard, the term "green economy" came into light. The Asian Center for Environment Management and Sustainable Development (AEMS) then explored the "green economy" concept in Nepal through a regional workshop on May 2012 with participants from Bangladesh, Bhutan, India, Canada, UK and Nepal. Consequently, the hydropower sector of Nepal was recognized as one of the most feasible and potential sector for green economy. Therefore, various case studies of hydropower projects, interaction programs and interviews with relevant personnel were carried out for this study to analyze the scope of hydropower in achieving the three important attributes of green economy, namely-resource efficiency, low carbon and social inclusion. Nepal is rich in water resources; it is therefore possible to use our abundant water resource in an efficient manner. Likewise, the end product of hydropower is clean energy though carbon emission is involved during the construction. It shows the potential to replace considerable amount of carbon emission from biomass based energy resources. Similarly, hydropower project exhibits positive implication on the local society besides making electricity available to the whole nation. The locals also get floating shares and royalty benefits to develop the project affected area. However, the affected areas now have minimal share in royalty. Besides, this study also addresses the issues of policy implication and challenges. All the relevant issues of hydropower as studied reveal that there are required provisions at place in Nepal for hydropower sector to fit perfectly in green economy concept, if only, the prevalent issues are handled efficiently and effectively by the relevant sectors.
\end{abstract}

Keywords: Green Economy; Sustainable Development; Social Inclusion; Hydropower; Low Carbon; Biomass Energy; Royalty

\section{Introduction}

\subsection{Background}

The economic growth the world has achieved is a double-edged sword [1]. On the one hand, it has generated extraordinary benefits-improving the standard of living of millions of people; on the other hand, it has caused unprecedented damage to environmental resources, which underpin our very existence and long-term welfare. Millions of people benefit from the current economic model, but the benefits are not distributed fairly. Economic development over the last few decades has failed to reduce poverty and create employment for majority of people living in poorer regions [2]. Furthermore, the economy is pushing the boundaries of environmental resources in terms of material consumption and pollution beyond what can be sustained by the Earth. However, we cannot just stop or reverse growth; rather it must be a priority as millions are still living in extreme poverty and hunger. We are, therefore, witnessing duel ecological and societal crises which may now be humanity's central challenge.

In order to address this dichotomy, the concept of sustainable development was introduced during the 1980s. Despite subsequent efforts, addressing this concept in developing national policies and plans has not been effective. This could be due to numerous possible reasons. A key one is ambiguity concerning the role of economic growth in achieving sustainable development [3]. Recently, green economy has emerged as a tool to further the concept of sustainable development. It advocates the 
transformation of our economy, by making it friendlier to environmental resources and poverty reduction.

\subsection{Defining Green Economy}

In early 2011, United Nations Environment Programme (UNEP) released its Green Economy Report, the product of multi-disciplinary research, which defined green economy (GE) as one that results in "improved human well-being and social equity, while significantly reducing environmental risks and ecological scarcities" [2]. In its simplest expression, a green economy can be described as one that is low carbon, resource efficient and socially inclusive.

\subsection{Green Economy for Nepal}

For developed countries to follow a green economy path, they must bear the costs of decarbonizing their economies; whereas Nepal already has a low-carbon economy and so can jump start its transition to a green economy. However, it has to maintain and/or expand further sustainable economic development practices. For example, it should: promote hydropower plants and economic activities like agriculture and tourism which are friendlier to environmental resources and less polluting. It should also strengthen the environmental protection policy as a national priority-Nepal is still committed to keeping a sizable part of the country covered by forest (currently about $37 \%$ of the total area is covered by forest and about $18.5 \%$ of total area is under protected areas). At the same time, the country should take steps to minimize unsustainable practices such as reducing the dependency of our population on natural resources-this degrades ecosystems and results in resource scarcity [4].

\subsection{Green Economy-Is It a Threat?}

The concept of green economy carries the promise of economic growth that is friendly to ecosystems and that also contributes to poverty alleviation. As such the green economy concept seems to offer solutions to Nepal's primary concerns-poverty and environmental protection. In this sense, transition to a green economy will entail moving away from the current system that has failed to be inclusive and share opportunities and benefits amongst disadvantaged groups. However, as the Panel of Experts reported to UN Commission on Sustainable Development in their report on The Transition to a Green Economy [5], this concept could be used to reinforce protectionist trends, enhance the conditionality associated with international financial cooperation, and unleash new forces that would reinforce international inequalities. The least developed countries like Nepal need to be careful regarding this "threat" and seek the opportunities that a green economy can bring to address their concerns about poverty and environmental protection.

\section{Adapting Green Economy Is Still a Challenge}

Despite its readiness, Nepal's transition to a green economy presents challenges. Definitely the economy needs to become inclusive, i.e. the benefits and opportunities of economic activities need to be shared equitably with disadvantages group, and not just be for elite groups. At the same time, we need to correct the current bias of the economy that causes unsustainable use of environmental resources. Environmental assets and services should support economic and social systems broadly and, more specifically, provide inputs to production. But, at present, they are undervalued or not valued at all, resulting in inefficient consumption of natural resources as well as environmental degradation. Similarly, the costs of environmental degradation (e.g. loss of forest, pollution of rivers and atmosphere, and solid waste disposal) are generally not paid by the polluters. Rather they are transferred to the public [6].

\subsection{Context for This Paper}

In the run-up to the UN RIO + 20 conference, a regional workshop on environmental mainstreaming for a green economy was organized on 3-5 May 2012 in Nepal jointly by the Asian Centre for Environment Management and Sustainable Development (AEMS), School of Environmental Science and Management (SchEMS) and the International Institute for Environment and Development (IIED). The workshop was attended by the participants representing countries in the Himalayan region —Bangladesh, Bhutan, India and Nepal.

Green economy is a new concept that is only just beginning to emerge in this region. However, the workshop confirmed that participating countries have been pursuing the path of wise environmental management and sustainable development for several decades-to varying degrees of success. An important conclusion of the workshop for Nepal was that hydropower development has internalized environmental and social considerations and could already be seen to be helping pursue a path to a green economy. Participants strongly recommended that a review be undertaken to examine if and how hydropower development in Nepal (both macro and micro) can be drive transformation to a green economy. This paper addresses this question and aims to open debate about the linkages between hydropower and the green economy in Nepal.

\section{Study Approach}

This study under took a multi-stakeholder Strength, Weakness, Opportunity and Threat (SWOT) analysis of 
hydro-power as a means of driving the green economy. We have adapted UNEP's definition of green economy, i.e. the green economy activity has to be low carbon, resource efficient and socially inclusive and thus improves human well-being and social equity, while reducing environmental risks and ecological scarcities. Thus, in order to establish if hydropower development in Nepal is a green economy activity, we ask the following questions:

- How is the issue of social inclusion addressed in hydropower development in Nepal?

- What sources of carbon are used in generating hydropower in Nepal?

- How efficiently is hydropower utilizing water resources in Nepal?

This paper places more emphasis on the first of the above questions. It is hoped that the outcome of the analysis will help the government in assessing GE progress to date and opportunities as it considers how to take up GE challenges in the aftermath of Rio + 20 and map out a practical transition roadmap.

\section{Results and Discussion}

\subsection{Efficiency of Utilizing Water Resources in Nepal-The Status of Hydropower Development in Nepal}

Nepal has tremendous potential of generating energy from its water resources. Some 6000 rivers drain about 200 billion $\mathrm{m}^{3}$ of water annually from Nepal. Figure 1 and Table 1 show the river basins and their electricity generation potentials.

The estimated hydropower potential of Nepal [7] shows a theoretical potential to generate approximately 83,000 MW (Table 1), of which about 42,000 MW is technically and economically viable. However, to date, Nepal has managed to generate only a very small portion of this potential-650 MW-less than $1 \%$ of what is economically viable. Table 2 below shows the current status of the hydropower projects in Nepal.

Though this situation appears disappointing for the hydropower in Nepal, there are many hydropower projects in the pipeline. About 50 projects are being processed and are in different stages of completion, with a total installed capacity of 2100 MW (see Table 3).

Nevertheless, progress in hydropower development in Nepal remains very slow and this situation is widely criticized. A blog article [9] sharply contrasts the slow pace of hydropower development in Nepal with the progress in neighboring countries. It highlights how Bhutan has forged an alliance with India and is now exporting 1500 MW of electricity to India. In addition, it has many mega projects ready in the pipeline for implementation. Similarly, small hill states in India-Himanchal Pradesh,

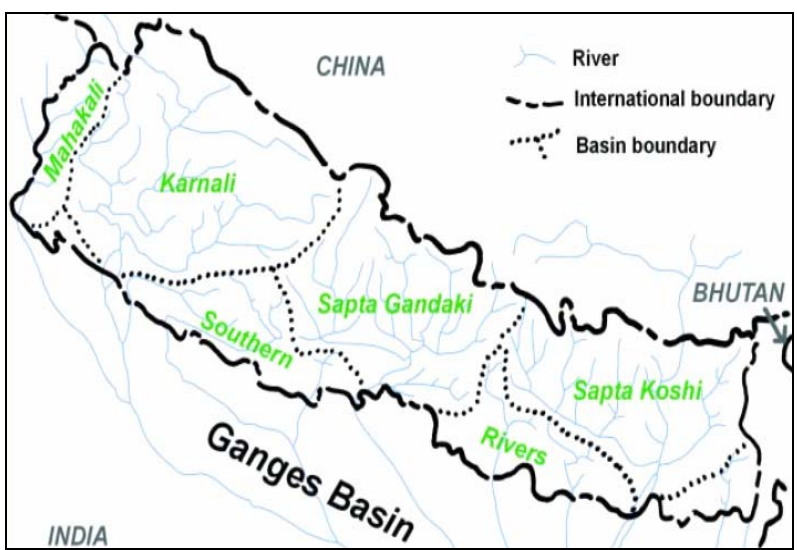

Source: Pokharel, 2001.

Figure 1. River basins of Nepal.

Table 1. Theoretical hydropower generation potential of Nepal.

\begin{tabular}{cccc}
\hline Basin & $\begin{array}{c}\text { Annual flow } \\
{\left[\text { billion } \mathbf{~ m}^{\mathbf{3}} \text { ] }\right.}\end{array}$ & $\begin{array}{c}\text { Catchment } \\
\text { area }\left[\mathbf{K m}^{\mathbf{2}}\right]\end{array}$ & $\begin{array}{c}\text { Potential } \\
{[\mathbf{M W}]}\end{array}$ \\
\hline SaptaKoshi & 33 & 28,140 & 22,350 \\
SaptaGandaki & 50 & 31,600 & 20,650 \\
Karnali & 42 & 41,890 & 32,010 \\
Mahakali & 7 & 5410 & 4160 \\
Southern Rivers & 42 & 40,141 & 4110 \\
Total & 174 & 147,181 & 83,280 \\
\hline
\end{tabular}

Source:Pokharel, 2001.

Table 2. Status of electricity generation from hydropower in Nepal.

\begin{tabular}{cccccc}
\hline SN & $\begin{array}{c}\text { Hydropower } \\
\text { plants }\end{array}$ & $\begin{array}{c}\text { Max } \\
{[\mathbf{M W}]}\end{array}$ & $\begin{array}{c}\text { Min } \\
{[\mathbf{M W}]}\end{array}$ & $\begin{array}{c}\text { No. of } \\
\text { plants }\end{array}$ & $\begin{array}{c}\text { Total } \\
\text { capacity }\end{array}$ \\
\hline 1 & Major hydro plants & 144.0 & 6.20 & 11 & 459.2 \\
2 & $\begin{array}{c}\text { Small hydro plants } \\
\text { [grid connected] }\end{array}$ & 3.2 & 0.10 & 16 & 13.8 \\
3 & $\begin{array}{c}\text { Small hydro plants } \\
\text { [isolated] }\end{array}$ & 0.5 & 0.03 & 23 & 4.5 \\
4 & $\begin{array}{c}\text { Private sector } \\
\text { hydro plants } \\
\text { Total }\end{array}$ & 60.0 & 0.20 & 22 & 166.9 \\
& & & 72 & 644.4 \\
\hline
\end{tabular}

Source: FNCCI, 2011.

Arunachal Pradesh and Sikkim-are also progressing rapidly. Sherchan [9] asks "If the neighboring countries are faring so well, what is hindering hydropower development in Nepal?”

\section{Policy Inconsistency Hinders Hydropower Development}

Inconsistency at the policy level is widely criticized by hydropower sector professionals and is blamed for the slow pace of hydropower development. A consultation workshop held at SchEMS, Pokhara University, on 17 
Table 3. Hydropower projects in the pipeline.

\begin{tabular}{|c|c|c|c|c|c|}
\hline SN & Hydropower plants & $\begin{array}{l}\text { Max } \\
{[\text { MW] }}\end{array}$ & $\begin{array}{c}\text { Min } \\
{[\mathrm{MW}]}\end{array}$ & $\begin{array}{l}\text { No. of } \\
\text { plants }\end{array}$ & $\begin{array}{l}\text { Installed } \\
\text { capacity }\end{array}$ \\
\hline 1 & Under construction & & & & \\
\hline 1.1 & Major hydro project & 456.0 & 14.0 & 4 & 500.40 \\
\hline 1.2 & Private sector project & 9.9 & 0.9 & 8 & 47.31 \\
\hline 2 & $\begin{array}{l}\text { Hydro project with } \\
\text { PPA concluded }\end{array}$ & & & & \\
\hline 2.1 & Private sector projects & 19.0 & 0.1 & 27 & 136.23 \\
\hline 3 & $\begin{array}{c}\text { Hydro project } \\
\text { [planned or proposed] }\end{array}$ & & & & \\
\hline \multirow[t]{2}{*}{3.1} & Major projects & 600.0 & 27.0 & 8 & 1422.00 \\
\hline & Total & & & 47 & 2105.94 \\
\hline
\end{tabular}

Source: FNCCI, 2011.

September 2012 for hydropower developers, user groups, experts as well as government authorities identified how initial hydropower-friendly government policies, introduced in the early 1990s, were later revised (repeatedly), ruining the investment environment for hydropower in Nepal. As a result, stakeholders (particularly potential investors) are now unsure what approach to take.

The first comprehensive regulations for the hydropower sector were the Hydropower Regulations 1992. They were introduced with related legislative instruments -the Water Resources Act 1992 and Regulation 1993, and the Electricity Act 1993 and Regulation 1993. The primary intensions of these were to address the growing demand for electricity and to reduce the populations' dependency on firewood to protect forest resources [8]. They also aimed to create an investment-friendly environment to encourage the rapid development of hydropower. The incentives provided by the Hydropower Policy 1992 are indicated in Table 4. This progressive policy led to two major projects with foreign investment (Khimti-60 MW, BhoteKoshi-36 MW) and a few locally-financed projects such as the Indrawati Project (5 MW) $[9,10]$.

Although participation of the private sector was a laudable aim of the policy, it failed to attract significant investment because it particularly promoted small scale projects to meet the demand of hilly and remote areas where electrification was lacking. The policy did not envision mega projects to provide electricity for export [11]. All of the energy produced by hydro-electric plants had to be sold to the Nepal Electricity Authority (NEA), i.e. this policy helped to establish the NEA as a monopoly buyer as well as supplier of electricity for Nepal. This situation has burdened NEA with the potential of having to bear an excessive electricity load which it might not be capable of handling. As a result, the policy could not attract investment for the mega hydro-electric projects; particularly foreign investment.
Table 4. Incentives and provisions of the hydropower policies of 1992 and 2001.

\begin{tabular}{|c|c|c|}
\hline Particulars & $\begin{array}{l}\text { Hydropower } \\
\text { policy-1992 }\end{array}$ & $\begin{array}{l}\text { Hydropower } \\
\text { policy-2001 }\end{array}$ \\
\hline \multirow{2}{*}{$\begin{array}{l}\text { Validity of } \\
\text { generation } \\
\text { license }\end{array}$} & 50 years & 35 years \\
\hline & $\begin{array}{l}\text { Concessional loan to } \\
\text { project }<1000 \mathrm{~kW}\end{array}$ & $\begin{array}{l}\text { Rs } 100-200 \text { per } \mathrm{kW} \text { per } \\
\text { annum and } 1.75 \% \text { - } 2 \% \text { of } \\
\text { average sale for } 15 \text { years }\end{array}$ \\
\hline \multirow[t]{2}{*}{ Royalty } & $\begin{array}{l}\text { Rs } 100 \text { per } \mathrm{kW} \text { per } \\
\text { annum and } 2 \% \text { average } \\
\text { sale for } 15 \text { years }\end{array}$ & $\begin{array}{l}\text { Rs } 1000-1500 \text { per } \mathrm{kW} \\
\text { per annum and } 10 \% \text { of } \\
\text { sales after } 15 \text { years }\end{array}$ \\
\hline & $\begin{array}{l}\text { Rs } 1000 \text { per } \mathrm{kW} \text { per } \\
\text { annum and } 10 \% \text { of } \\
\text { average sale after } 15 \text { years }\end{array}$ & $\begin{array}{l}1 \% \text { of royalty transfer to } \\
\text { DDC }\end{array}$ \\
\hline \multirow[t]{2}{*}{ Concession } & $\begin{array}{c}\text { Concession loan to } \\
\text { project }<100 \mathrm{~kW}\end{array}$ & \\
\hline & $\begin{array}{c}\text { No income tax for }<1000 \\
\mathrm{~kW}\end{array}$ & $\begin{array}{l}\text { Taxation as per } \\
\text { prevailing tax act }\end{array}$ \\
\hline \multirow[t]{2}{*}{ Income tax } & $\begin{array}{l}15 \text { years tax holiday for } \\
\text { plants }>1000 \mathrm{~kW}\end{array}$ & \\
\hline & $\begin{array}{l}10 \% \text { less in income tax } \\
\text { when relevant }\end{array}$ & \\
\hline \multirow[t]{2}{*}{$\begin{array}{l}\text { Custom/sales } \\
\text { tax }\end{array}$} & $\begin{array}{l}1 \% \text { custom on goods not } \\
\text { produced in Nepal. }\end{array}$ & $\begin{array}{l}1 \% \text { customs duty. } \\
\text { No VAT as long as } \\
\text { VAT is not charged } \\
\text { on electricity. }\end{array}$ \\
\hline & $\begin{array}{l}\text { No import licenses/sales } \\
\text { tax }\end{array}$ & \\
\hline \multirow[t]{2}{*}{ Energy rate } & $\begin{array}{c}\text { Allowance of } 25 \% \\
\text { dividend on share capital }\end{array}$ & \\
\hline & $\begin{array}{l}\text { Private land acquisition } \\
\text { as per Land Acquisition } \\
\text { Act } 2034\end{array}$ & $\begin{array}{c}\text { Private land acquisition as } \\
\text { per Land Acquisition Act } \\
2034\end{array}$ \\
\hline Land & $\begin{array}{l}\text { Government land to be } \\
\text { available on lease } \\
\text { throughout the license } \\
\text { period }\end{array}$ & $\begin{array}{l}\text { Government land to be } \\
\text { available on lease } \\
\text { throughout the license } \\
\text { period }\end{array}$ \\
\hline $\begin{array}{l}\text { One window } \\
\text { policy }\end{array}$ & Provided & $\begin{array}{c}\text { Provided by Department } \\
\text { of Electricity } \\
\text { Development (DoED) }\end{array}$ \\
\hline $\begin{array}{l}\text { Geo-hydrologic } \\
\text { risk }\end{array}$ & NA & $\begin{array}{l}\text { License extent up to } 5 \\
\text { years as compensation }\end{array}$ \\
\hline $\begin{array}{l}\text { Resettlement } \\
\text { cost }\end{array}$ & NA & $\begin{array}{l}\text { Cost to be bared by the } \\
\text { developer }\end{array}$ \\
\hline Security cost & NA & $\begin{array}{l}\text { Cost to be bared by the } \\
\text { developer }\end{array}$ \\
\hline $\begin{array}{l}\text { Institutional } \\
\text { provision }\end{array}$ & NA & $\begin{array}{c}\text { Formation of: Regulation } \\
\text { body i.e. Nepal Electricity } \\
\text { Regulation Committee } \\
\text { (NERC). Study body i.e. } \\
\text { Water and Energy } \\
\text { Commission Secretariat } \\
\text { (WECS). Promotional } \\
\text { body i.e. DoED. } \\
\text { Unbundling of Nepal } \\
\text { Electricity Authority } \\
\text { (NEA). Electric energy } \\
\text { management institution }\end{array}$ \\
\hline
\end{tabular}

Source: Sherchan, 2008a; Adhikari, 2011. 
Less than a decade later, the Hydropower Policy 1992 was amended by the Income Tax Act 2001, thus introducing a new Hydropower Policy. This policy tried to address the above deficiencies by allowing the possibility for developers to export hydropower energy to the neighboring market (India) through the concept of BOOT —-Build, Operate, Own and Transfer [12]. However, this policy change has been widely criticized by the Nepalese people who suffer from frequent and ongoing load shedding. They ask why Nepal is promoting export-oriented hydropower investments when it is suffering itself from electricity deficiency. Furthermore, the new policy was not popular amongst developers as it also revoked some of the progressive provisions of the 1991 policy. For example, it reduced the validity of hydropower generation licenses from 50 to 35 years, introduced an incremental royalty payment, scrapped an income tax holiday and brought hydropower projects under the usual corporate tax net of $21.5 \%$ (see Table 4).

Following the amendment to the Hydropower Policy 2001, the government introduced an ordinance in July 2006 negating all previous relevant policies and making value added tax (VAT) applicable to all hydropower projects above $3 \mathrm{MW}$. This ordinance resulted in an immediate $13 \%$ escalation of the costs of all hydropower projects above $3 \mathrm{MW}$.

\subsection{Hydroelectricity Is a Strong Alternate to Fuel Wood to Reduce Carbon Emissions}

There is a little doubt that hydroelectricity is cleaner-in terms of carbon release-than the other sources of energy such as fossil fuels or biomass-based fuels. We have carried out a simple calculation to determine the amount of carbon being prevented from release by current hydroelectric plants in Nepal.

\section{Estimation of Carbon Release from the Biomass-Based Energy Sources}

Biomass energy accounts for 38\% of the primary energy consumption in developing countries [13]. In addition, more than $90 \%$ of rural energy in developing countries is derived from biomass [14]. In Nepal, biomass energy comprises fuel wood, agricultural residues and animal waste which is used in residential, industrial and service sectors. Biomass energy is available freely from nature (i.e. through fuel wood collection) or can be a byproduct of agricultural activities (agricultural residues and animal dung) [15]. In the past, the supply of biomass energy was abundant but has been steadily declining in recent years due to the growing population, reduction in forested areas and rising demand for energy. The rural people of Nepal rely mainly on freely accessible biomass to meet their daily energy needs - they have no alternatives [16]. Traditionally, biomass supplies around $87.71 \%$ of the total energy consumed in Nepal, with, 78.14\% provided by firewood alone [17].

We have made a simple estimation on how much carbon release the current hydropower projects have prevented which otherwise would have been released if firewood had been used. As indicated in Table 5, 35,087 kTon of $\mathrm{CO}_{2}$ is released by burning fuelwood to generate 310 million GJ of energy in Nepal. The current total installed hydroelectricity plant of 644.4 MW generates almost 20.2 million GJ. As a result, $2282 \mathrm{kTon}$ of $\mathrm{CO}_{2}$ is prevented from release annually. In order words, if Nepal could generate 9909 MW of electricity from hydropower plants, the current 310 million GJ supplied from burning fuelwood could be saved, and that could preserve the precious forest resources of Nepal. There is, of course, a broader challenge of connecting rural energy users to such hydropower supplies which suggests that locallylocated micro-hydropower schemes are the key option.

\subsection{Social Inclusion-Benefit Sharing from the Hydropower}

The electricity generated from the hydro plants is usually transferred to the cities and industries. Furthermore, the revenue generated from the electricity sales goes the government, and the profits go to the investors and the distributor, i.e. NEA. However, the local communities in the areas around hydro projects often do not get direct benefits from hydro schemes. Yet they have to endure environmental and social impacts resulting from these projects such as displacement, loss of property and livelihoods, loss of access to environmental resources, etc.

Table 5. Some energy factors for Nepal.

\begin{tabular}{|c|c|}
\hline $\begin{array}{l}\text { Total national } \\
\text { energy } \\
\text { requirement }\end{array}$ & $\begin{array}{l}\text { Per capita energy consumption: } 15 \text { GJ [18] } \\
\text { Total energy consumption of Nepal's } 26.5 \\
\text { populations: } 397.5 \text { million GJ [19]. }\end{array}$ \\
\hline $\begin{array}{l}\text { Energy supplied } \\
\text { by fuelwood }\end{array}$ & 310 million GJ (78.14\% of 397.5 million GJ). \\
\hline $\begin{array}{c}\text { Total } \mathrm{CO}_{2} \\
\text { released } \\
\text { by fuelwood }\end{array}$ & $\begin{array}{l}\text { According to IPCC, } 1 \mathrm{~kg} \text { of wood is equivalent to } \\
0.0162 \mathrm{GJ} \text { and emits } 1.83 \mathrm{~kg} \mathrm{CO}_{2} \text { [20], i.e. } 310 \\
\text { million GJ of energy is equivalent to } 35,087 \mathrm{kilo} \\
\text { ton of } \mathrm{CO}_{2} \text {. Hence with the decline of fuelwood } \\
\text { consumption, a considerable amount of } \mathrm{CO}_{2} \text { can } \\
\text { be saved. }\end{array}$ \\
\hline $\begin{array}{l}\text { Total energy } \\
\text { generated from } \\
\text { hydropower }\end{array}$ & $\begin{array}{c}\text { The installed total capacity of hydroelectricity in } \\
\text { Nepal is } 644.4 \mathrm{MW} \text {, i.e. 5,644,944 MWh (1 MW } \\
=8760 \mathrm{MWh} \text { - - equivalent to 20,160,514.3 } \\
\text { GJ (1 GJ = 0.28 MWh). }\end{array}$ \\
\hline $\begin{array}{l}\text { Total } \mathrm{CO}_{2} \text { (fuel } \\
\text { wood equivalent) } \\
\text { release prevented } \\
\text { by hydropower }\end{array}$ & $\begin{array}{l}\text { Hydropower projects/plants contribute to carbon } \\
\text { release, mostly during construction phase } \\
\text { (removal of trees, burning of fossil fuel by } \\
\text { construction equipment, use of fuel wood by } \\
\text { workers) and also in the form of methane from } \\
\text { reservoirs. However, we have assumed that } \\
\text { these releases are insignificant in compare } \\
\text { to the carbon release from other sources. }\end{array}$ \\
\hline
\end{tabular}


[21]. This issue has become a serious concern. It can cause conflict between projects and local communities and lead to obstruction of project implementation.

The policies have aimed to encourage private sector investment in hydropower projects. But two facts need to be bore in mind. Firstly, such projects are intended as profit-oriented ventures and investors will only risk their capital if there is the realistic hope of a return. Secondly, the nation is also investing in such projects by allowing the use of its resources, i.e. water and land. This construct does not involve the notion of benefit-sharing between investors and the nation. However, both developers and the government need to involve local communities as partners and enable them to equitably share the benefits. The hydropower policies do not deal with this issue directly, but it has been addressed through three mechanisms:

1) Sharing of the hydropower royalty;

2) Floating shares in hydropower projects to local people;

3) Environmental and social management plans.

\subsubsection{Social Inclusion-Hydropower Royalty Sharing}

The developer pays a royalty to the government treasury as a rent for the resources being used. There was a huge debate concerning whether the royalties for projects generating electricity for domestic use should be different than those for export purposes. It was argued that domestic consumption projects will enhance the value of the nation's economy by promoting further development. Thus the Hydropower Policy 2001 introduced two royalty rates. The royalty rates for projects supplying electricity for domestic consumption are shown in Table 6; and those for export projects in Table 7.

The requirement that hydropower developers should pay a royalty to the government for projects generating above $1 \mathrm{MW}$ was included in the Hydropower Policy 1992. But it did not specify how the amounts received should be used [22]. In 1999, the Local Self-Governance Act and Local Self-Governance Regulations accepted the

Table 6. Royalty rates for the domestic consumption projects.

\begin{tabular}{|c|c|c|c|c|c|}
\hline \multirow{2}{*}{$\begin{array}{r}\text { SN } \\
1\end{array}$} & \multirow{2}{*}{$\begin{array}{c}\text { Capacity } \\
\text { Up to } 1 \text { MW }\end{array}$} & \multicolumn{2}{|c|}{$\begin{array}{l}\text { Up to } 15 \text { years from } \\
\text { the date of } \\
\text { commercial production }\end{array}$} & \multicolumn{2}{|c|}{$\begin{array}{l}\text { After } 15 \text { years from } \\
\text { the date of commercial } \\
\text { production }\end{array}$} \\
\hline & & & - & & 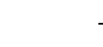 \\
\hline 2 & $\begin{array}{l}\text { From } 1 \mathrm{MW} \\
\text { to } 10 \mathrm{MW}\end{array}$ & Rs 100 & $1.75 \%$ & Rs 1000 & $10 \%$ \\
\hline 3 & $\begin{array}{c}\text { From } 10 \mathrm{MW} \\
\text { to } 100 \mathrm{MW}\end{array}$ & Rs 150 & $1.85 \%$ & Rs 1200 & $10 \%$ \\
\hline 4 & Above $100 \mathrm{MW}$ & Rs 200 & $2.00 \%$ & Rs 1500 & $10 \%$ \\
\hline 5 & For captive use & Rs 1500 & - & Rs 3000 & - \\
\hline
\end{tabular}

Source: Ministry of Water Resources (MoWR), 2001.
Table 7. Royalty rates for the export-oriented projects.

\begin{tabular}{cccccc}
\hline SN & Type & \multicolumn{2}{c}{$\begin{array}{c}\text { Up to } 15 \text { years from } \\
\text { the date of commercial } \\
\text { production }\end{array}$} & \multicolumn{2}{c}{$\begin{array}{c}\text { After } 15 \text { years from } \\
\text { the date of commercial } \\
\text { production }\end{array}$} \\
1 & Run-of-river & Rs 400 & $7.5 \%$ & Rs 1800 & $12 \%$ \\
2 & Storage & Rs 500 & $10 \%$ & Rs 2000 & $15 \%$ \\
\hline
\end{tabular}

Source: Ministry of Water Resources (MoWR), 2001.

necessity to redistribute part of the royalty to communities in the vicinity of projects. This recognized the fact that communities contribute to projects by sacrificing access to or use of land and other resources in the areas affected by hydro projects. As a result, the Hydropower Policy 2001 included the provision to return 10\% of the royalty from a hydropower project to the district where it is located. It contains three key provisions regarding royalty sharing with local communities:

- The primary benefit of hydropower projects is the generation of electricity. Projects that intend to distribute electricity to local peoples (i.e. rural electrification projects) are encouraged (Clause 6.4 (6.4.3)) by exempting royalty for first 15 years from the date of commercial production.

- Clause 6.2 (6.12.1) states "provision shall be made such that the local people can also be directly benefitted from the operation of the hydropower generation project. Such provision shall be included in the agreement to be made with the licensee. In addition, $10 \%$ of the amount obtained for royalty shall be provided to the District Development Committees of those Districts affected from the dam, reservoir and powerhouse of those Districts affected from the dam, reservoir and power house constructed for the generation of hydropower, to be spent in development and construction work of those Districts, pursuant to the Local Self-governance rules”.

- Clause $6.4(6.4 .4)$ states " $1 \%$ of the royalty obtained by the Government from a hydropower project shall be provided to the Village Development Committees (VDCs) that are directly affected by the hydropower infrastructure with the sole purpose of expanding electrification of these VDCs" [23].

In 2004, the second amendment to the Self-Governance Regulations increased the district's share of the royalty to $12 \%$. In response, the new Electricity Ordinance (2007) made provision to share electricity royalties from a hydro project between the concerned District Development Committee (DDCs) (12\%)—which is then redistributed to Village Development Committee(s) (VDCs) adjoining the project, the Development Region (38\%), and the national exchequer (50\%) [24].

The Hydropower Policy 2001 does not stipulate organizational arrangements for distributing royalties. However, the Ministry of Energy recommends to the Ministry 
of Finance allocations through fiscal budgets to the DDCs with hydropower plants. The website of the Department of Electricity Development publishes the royalty distribution per DDC [25]. This reports that a total of NRs 390 million (US \$4.7 million) was distributed in fiscal year 2011-2012 [26].

Currently only 66 of Nepal's 75 DDCs have hydropower plants, and are receiving the hydro royalty. Moreover, the size of royalty received by these 66 DDCs varies depending on the size of their hydropower plants. In some cases, it could be a significant proportion of total revenues. For example, in fiscal year 2001-2002, hydropower royalties represented $65 \%$ of the revenues of Makawanpur District Development Committee. In 20112012, Makawanpur is still the leader in receiving royalties from hydropower-earning NRs 3.24 billion (US \$3.85 million) [26].

Some of the experienced DDCs have prepared their own guidelines for royalty management. Makawanpur DDC is one of the pioneers of the hydropower sectorthe district has the only storage plant in the country (Kulekhani)—and has prepared the "Hydropower Royalty Distribution and Use Directive 2006". This requires the DDC to invest half of the $12 \%$ royalty it receives in the hydropower affected area, while the remaining half can be used in other areas [27].

The Local-Self Governance Act and Regulations determine how funds received by DDCs or VDCs shall be used. These committees are elected bodies supported by government officials. So, where areas affected by hydro projects are not represented on a DDC, there is a possibility that royalties can be diverted away from those areas. Considering this possibility, Clause 6.4 (6.4.4) of the Hydropower Development Policy 2001 stipulates that $1 \%$ of the royalty obtained by the government from a hydropower project shall be provided to the Village Development Committees (VDCs) that are directly affected by the hydropower infrastructure concerned. The $1 \%$ margin might be substantial for DDCs with big scale hydropower projects, but this is inadequate for the DDCs with smaller projects. The distribution of the royalty to the actual affected people is most critical in such cases. The DDC that receives NRs 130,000 (USD 1500) as a royalty, would be required to allocated only NRs 1300 (USD 150) to the affected VDC for the whole year. Furthermore, this meager amount will be further divided if there is more than one directly affected VDCs. This is one of the reasons why local inhabitants have become skeptical about hydropower projects and escalates the tensions between affected families and developers. During our consultations with families affected by hydropower schemes and also with developers, they have unanimously expressed the view that the hydro royalty should be directly invested in the affected VDCs and for the benefit of affected families.

\subsubsection{Social Inclusion through Floating Shares to the Affected Communities}

Ensuring long term benefit-sharing with local communities, particularly affected families, is achieved by allocating shares in the hydropower project. The amended Securities Registration and Issuance Regulation 2008 provide for floating share to local people. According to the amendment, a company has to float a minimum of $30 \%$ of its issued capital, unless otherwise directed by the company's regulatory body. Of this $30 \%$, five per cent has to be made available to the company's staff, $10 \%$ to the local community, and the remaining $15 \%$ to the general public. However, the locals cannot sell their share in the first three years. The amendment directs that "If a person applies for the share that is separated to the locals, he/she cannot apply for the shares separated to the general public [28].”

\subsubsection{Environmental Legislation Ensures Social Inclusion and Reduces Impact on Environmental Resources}

One of the pre-requisites for obtaining a power generation license is the Environmental Clearance. The Environmental Protection Act 1996 and Regulations 1997 require the mandatory application of Environmental Impact Assessment (EIA) for projects above $5 \mathrm{MW}$ and Initial Environmental Examination (IEE) for projects between 1 and $5 \mathrm{MW}$. These provisions are made to ensure the mitigation of any negative environmental and social impacts of the project. However, developers have been complaining about the bureaucratic problems created by this provision. On one hand, a large number of ministries and departments are involved, e.g. Department of Energy Development, Ministry of Energy, Ministry of Forests and Soil Conservation and Ministry of Environment. This results in a lengthy process to obtain the Environmental Clearance causing delays in project implementation. On the other hand, the developers have themselves been found to undermine environmental studies resulting in poor quality EIA and IEE studies. As a result, the authorities are reluctant to readily issue Environmental Clearance documents.

The ordinance 2006 supersedes the provisions of the environmental legislation. Now projects with an installed capacity between 1 and 50 MW are only subjected to IEE, with those greater than $50 \mathrm{MW}$ requiring a full EIA. This change might be seen to favor the developers, but the sustainability of projects might be threatened if critical impacts on bio-physical resources or effects on people are neglected or ignored.

Hydropower development in Nepal provides numerous benefits. Apart from supporting green economy, it also offers other benefits as illustrated by the case study of Middle Marsyangdi Hydropower project (Table 8). 
Table 8. Case study of macro hydro power project: middle marsyangdi.

The Middle Marsyangdi Hydro Electric Project (MMHEP) lies in Lamjung District of the Western Development Region of Nepal. Ithas an installed capacity of 70 MW (380 GWh per year) [29]. Construction started in 2001 [30]. An EIA study was mandatory for this project due to the environmental impacts associated with its construction and operation.

The EIA identified a number of likely impacts: displacement of local population (306 household estimated), cutting of trees (3475 estimated trees), changes in river morphology (run-off river project) etc. [30]. With these in mind, environment mitigation and monitoring plan was prepared and the total cost of environmental management was estimated to be US\$ 2.92 million [29]. The project area people were more particularly interested in compensation, rehabilitation and relocation issues. Hence for the relocated families, there were provisions of comprehensive compensation and rehabilitation plans and budget as shown in the table below. There were also relocation program for households losing their land (their households) in nearby areas and also provision of disturbance or hardship allowances. According to the EIA study, the affected households were positive towards the project [30].

Major information on Middle Marsyangdi Hydro Electric Project (in US \$)

Particulars Data

Resettlement and rehabilitation costs

US \$1.77 million

Land acquisition

US $\$ 1.72$ million $=62.9 \%$ of total resettlement and rehabilitation costs

Breakdown of resettlement and rehabilitation costs 62.9\% land acquisition, 9.63\% house acquisition, 2.19\% compensation for trees

Relocation costs As per need

Additional cost $10.56 \%$ for other rehabilitation

Source: ADB, 2006.

Likewise, the locals were also given an opportunity to work in the project areas and to enhance their skills. Programmes were introduced providing agricultural extension and training, off-farm skill development training, community development, environmental improvement, etc. There was also a community development programme providing support to rehabilitate a rural agricultural road, an education facility, and rural irrigation works, etc. In addition, an Environmental Unit was established to ensure effective implementation and monitoring of the environmental management action plan. The EIA study showed that there would be no immitigable damage caused by the project [30].

The project will also provide royalty benefits. The Nepal Electricity Authority gave a royalty rate of NRs 4.8 per unit of electricity to Siuri hydropower project (5 MW) in Lamjung District for projects functioning 24/7 without disruption. Assuming this rate is applied, the Middle Marsyangdi project (70 MW) will earn NRs 241,920,000 (\$2,880,000/month). As per the Cabinet decision, 1\% of this total sum must be directed to the affected VDC’s i.e. NRs 2,419,200 (\$28,800/month).

This case shows that a significant amount of beneficial impacts will accrue to the project area. In addition, this project has helped to meet the power demand of the country and boost its economy.

\section{Conclusions and Recommendations}

The current study shows the high potential of the hydropower sector to help transform Nepal towards a green economy. The country's rich water resources have the potential to generate 83,000 MW of power. However, only $650 \mathrm{MW}$ is harnessed so far showing that Nepal has not been able to use its potential to the optimum. It lags behind India and Bhutan in hydropower generation. One key reason is the confusion created by the hydropower policy. Also the responsibilities and jurisdictions of the numerous government bodies involved in water management are poorly defined.

Hydropower development is not necessarily a zero carbon technology. But, as discussed above, it can save a significant amount of $\mathrm{CO}_{2}$ emissions that other energy sources are currently generating. The population of Nepal relies highly on traditional energy supplies-commonly fuel wood which produced high $\mathrm{CO}_{2}$ emissions and its gathering disrupts ecosystem functioning. Hence replacing fuel wood with hydropower can considerably reduce carbon emissions. The carbon emissions resulting from hydropower development during construction and from other sources are negligible.

Besides proving resource efficient and low carbon en- ergy, hydropower development fosters social inclusion. And royalties support social empowerment. However, there is a need to amend the hydropower policy since not all VDCs benefit in the same manner. Addressing this issue will encourage a positive and supportive attitude towards hydropower projects amongst local people-one of the main reasons for conflict between hydropower projects and surrounding communities is their lack of access to royalties. Transparent royalty management and strong monitoring and enforcement would improve the impact of royalties and increase support amongst local people.

This study shows that the required provisions for hydropower development are already at place, but need some amendment. Also, Nepal has a long history of hydropower development (over a century now) along with abundant expertise, and the hydropower sector can flourish if careful attention is given to its management.

\section{Acknowledgements}

The authors are grateful to all the stakeholders who supplemented us with the valuable information. We also thank Dr. Barry Dalal Clayton, Senior fellow, IIED for his significant contribution in preparing this paper. Fi- 
nally, the study was undertaken with financial support from IIED under an accountable grant provided to IIED by UK DFID.

\section{REFERENCES}

[1] Ecological Society of America (ESA), "Ecological Impacts of Economic Activities,” 2012.

[2] UNEP, UNCTAD and UN-OHRLLS, "Green EconomyWhy a Green Economy Matters for the Least Developed Countries," UNEP, United Nations UNCTAD, UNOHRLLS, 2011.

[3] M. S. Lele, "Sustainable Development: A Critical Review," World Development, Vol. 19, No. 6, 1991, pp. 607-621. doi:10.1016/0305-750X(91)90197-P

[4] AEMS, "Environmental Mainstreaming for a Green Economy,” AEMS/SchEMS/IIED, Kathmandu, 2012.

[5] J. A. Ocampo, "The Transition to a Green Economy: Benefits, Challenges and Risks from a Sustainable Development Perspective,” UNEP, UN-UNCTAD, undated.

[6] B.-D. Clayton, et al., "Safeguarding the Future, Securing Shangri-la,” IIED, AEMS, 2012.

[7] H. M. Shrestha, "Cadastre of Potential Water Power Resources of Less Studied High Mountainous Regions, with Speical Reference to Nepal," Moscow Power Institute, USSR, Moscow, 1966.

[8] MoWR, “The Hydropower Development Policy, 1992,” MInistry of Water Resources (Now Ministry of Energy), Government of Nepal, Nepal, 1992.

[9] B. M. Sherchan, "Hydropower Development in NepalThe Developers' Dilemma,” Nepali Perspectives, Kathmandu, 2008.

http://nepaliperspectives.blogspot.com/2008/08/hydropo wer-development-in-nepal.html

[10] S. Pokharel, "Hydropower for Energy in Nepal," Mountain Research and Development, Vol. 21, No. 1, 2001, pp. 4-9. doi:10.1659/0276-4741(2001)021[0004:HFEIN]2.0.CO;2

[11] R. S. Shrestha, "An overview of Hydropower Policy," Ratna Sansar Shrestha, FCA [blog], Kathmandu, 2010.

[12] M. R. Ghimire, "Present Hydropower Development Policy in Nepal,” Regulating Network [Blog], Kathmandu, 2011. http://regulatingnetwork.blogspot.com/2011/11/present-h ydropower-development-policy.html

[13] D. O. Hall, et al., "Biomass Energy Supply and Prospects,” In: H. K. Johansson, A. K. Reddy and R. H. Williams, Eds., Renewable Energy: Sources for Fuel and Electricity, Island Press, Washington DC, 1993.

[14] S. C. Bhattacharya and P. Abdul-Salam, "Low Greenhouse Gas Biomass Options for Cooking in the Developing Countries," Biomass and Energy, Vol. 22, No. 4, 2002, pp. 305-317. doi:10.1016/S0961-9534(02)00008-9

[15] S. Pokharel, "Kyoto Protocol and Nepal's Energy Sector,” Energy Policy, Vol. 35, No. 4, 2007, pp. 2514-2525.

\section{doi:10.1016/j.enpol.2006.09.015}

[16] ICIMOD/ADB, “Environment Assessment of Nepal: Emerging Issues and Challenges,” Asian Development Bank/International Center for Integrated Mountain Development, Kathmandu, 2006.

[17] WECS, "Energy Synopsis Report," Water and Energy Commission Secretariat, Kathmandu, 2006.

[18] S. R. Shakya, “Application of Renewable Energy Technology for Greenhouse Gas Emission in Nepalese Context: A Case Study," The Nepalese Journal of Engineering, Vol. 1, No. 1, 2005, pp. 92-101.

[19] CBS, "Preliminary Result of National Population Census,” Central Bureau of Statistics, Kathmandu, 2012.

[20] IPCC, "Revised Guidelines for National Greenhouse Gas Inventories,” Intergovernmental Panel on Climate Change, Geneva, 1996.

[21] C. Wang, "A Guide for Local Benefit Sharing in Hydropower Projects,” The World Bank, Washington DC, 2012.

[22] E. G. R. E. Dominique, "Compendium on Relevant Practices-2nd Stage. Dams and Development Project," United Nations Environment Programme, 2007.

[23] MoWR, “The Hydropower Development Policy, 2001,” Ministry of Water Resources (Now Ministry of Energy), Government of Nepal, 2001.

[24] Singh, D. B. "Balancing Energy Food Natural Resources and Environment in Nepal (An Assessment of 6720 MW Pancheshwar Multipurpose Project),” 2010. www.worldenergy.org

[25] DoED, Department of Electricty Development, "Royalty Management," 2011.

http://www.doed.gov.np/notices/Royalty-Management-20 68-06-25.pdf

[26] Department of Electricity Development "Royalty Management and Distribution," Department of Electricity Development (DoED), Ministry of Energy, Government of Nepal, 2011.

[27] L. Joshi, “A Community-Based PES Scheme for Forest Preservation and Sediment Control in Kulekhani, Nepal (Case Study 9),” In: D Ottaviani and N.-H. Scialabba, Eds., Payment for Ecosystem Services and Food Policy, ICIMOD, Rome, 2011, pp. 114-123.

[28] K. Chalise, "Business and Economy: Hydropower Companies Must Float Shares for Locals,” Kathmandu, Nepal, 2010.

[29] ADB, "Nepal: Preparation of National Resettlement Policy,” Asian Development Bank, Kathmandu, 2006.

[30] D. B. Singh, "Nepal Case Study on Environmental Impact Assessment of Middle-Marsyangdi Hydro Electric Project,” Department of Electricity Development, Kathmandu, 2003.

[31] FNCCI, "Federation of Nepalese Chambers of Commerce and Industry. Hydro Power Projects 2009/2010, 2011 (online). http://www.fncci.org/text/pp-eup.pdf. 